information must also be made available to all interested analysts. The American system of relaying such information is noteworthy. Where tolerances are fixed, methods of assay can often be simplified by reference to a standard. In matters of doubt, complete unanimity of opinion in all countries is improb. able; but free discussion and free exchange of information could assist in reaching sensible conclusions. Piecemeal decisions should beavoided if possible.

Dr. Bernard Oser suggested that while it is not generally possible to legislate for allergic subjects, some protection might be achieved by appropriate labelling.

It was perhaps surprising that Mr. Bacharach's dismissal of some of the fears felt by those who mistrust the use of antibiotics was not contested.

Mr. Wesley Dunn said that the value of the meeting lay in the opportunity it had provided for discussion of a problem common to many interests, thereby making progress towards its ultimate solution. Sir Harry Jephcott, in summing up, thought uniformity had been brought nearer by this international exchange of ideas, and hoped that this had been only the first of many similar joint meetings.

The papers before the conference will be published in the Food, Drug and Cosmetic Law Journal.

\section{MORALE IN INDUSTRY}

N 1953, the Acton Society Trust published, under the title "Size and Morale", the results of an inquiry into the statistically observable relationship between the size of a number of otherwise similar undertakings-in a coalfield, in a large industrial organization, in a commercial group-mand certain indices of morale among the workers employed in these undertakings (see Nature, February 27, 1954). Size was defined according to the numbers of workers on the books. Morale was measured by various indices of which the most important was the negative one of absenteeism-since, to quote the pamphlet in question, "a man can hardly express his identification with his work more clearly than by whether or not he turns up to perform it".

The results of the inquiry were extremely sugges. tive. In the coalfield studied, not only was lost time found to increase with size, but it was also established statistically that in similar geological conditions output per man-shift tended to be no higher--and was often in fact appreciably lower--in large pits than in small. Various forms of behaviour suggested that workers in small pits showed greater interest in matters associated with their place of work than those in larger pits. Wages did not appear to have any effect on morale, and it was interesting to find this statistically confirmed. A clear relationship was found to exist between size and sick-leave; between size and the number of accidents; and also between size and the length of time taken to recover from an accident. All this evidence was entirely quantitative and not very useful as a guide to policy. The fact that the size of the unit in which people work is related to their behaviour is not an explanation of the relationship. The earlier studies stopped short at statistical domonstration; they made no attempt to explain what they demonstrated in sociological terms.

The next stage of inquiry called for a different approach, the approach of the social scientist working in inclividual situations. The inquiry has now been completed and a second report issued*. It is a qualitative study which tries to find out the reasons for the higher lost time in large establishments and, where practicable, to draw lessons from management policy.

The inquiry was made in a group of twelve manufacturing units which came as near as possible to the ideal requirements for the research. Units of the group varied in size from about twenty to about four thousand people; five of the units were selected for special investigation.

The works selected for study all offered the same wage-rates and conditions of service and the same sick schemes and pension rates; thoy followed technically tho same patterns of work; they were all situated in a large urban area; they had all been under the $\operatorname{sam} \theta$ administration for many years. They were all alike in employing for the most part labour of an unsikilled or semi-skilled character, the small proportion of craftsmen being mainly occupied with maintenance rather than production. There was no significant difference in the age structure of their working forces--a matter which might well make a difference to time lost after accident or illness-nor in the average length of service.

The inquiry confirmed the inverse size-morale effect and showed that poor morale arises from causes which have nothing to do with the worker's satisfaction in, and psychological identification with, his work. Many reasons for good morale in small units were adduced. One is that very small units cannot carry bad time-keepers-they quickly dismiss them ; they cause too much dislocation to be tolerated. Evidence showed that the larger works had more than their statistical share of bad time-keepers. This was also true of grumblers, the rumour-mongers, and the chronically discontented trouble-makers. In the small unit such men are easily identified and, if possible, discharged. In the large unit they are likelier to remain submerged and unrecognized and it is in the large units that they are most likely to be found. The trouble-maker has much more scope in a large group. In the small unit, even if he cannot be discharged, he is comparatively innocuous because his colleagues know all about him and can discount what he says. In the large unit the majority do not know him for what he is, and his influence is consequently far more dangerous. His low morale and his high lost time-rate are contagious, and the morale and time-keeping of the works as a whole consequently suffer.

The most important lesson arising from the inquiry is that increasing size is above all an increasing challenge to managoment-management in the social even more than in the administrative or technical sense. There are disadvantages in size about which management can do little or nothing. A higher incidence of sickness due to greater likelihood of cross-infection is one of these. The wider catchment area for labour is another. So is the tendency of bad time-keepers and 'bad bargains' generally to gravitate to the larger unit. Other disadvantages of size isolated by the inquiry are not similarly intractable. There is no reason why internal discipline should be increasingly handicapped with increasing size by over-extension of the foreman's span of control. A good foreman with a manageable number of men under his control can generate a positive team spirit as well as performing the negative function of

- Size and Morale. Part II. Acton Society Trust. 3s. 6d. 
checking absenteeism and 'column-dodging' .It is management's job both to select the right foremen (which includes providing the right incentives to their recruitment) and to see that their span of control is suitable.

The importance of intermediate management is one of the obvious lessons of this, as of other related inquiries. In order that respect and trust may be generated, it is necessary both that intermediate positions be filled by men of ability and character and that the system within which they work should allow decisions to be made quickly, unequivocally and comprehensibly at the appropriate point. Both the choice and appointment of subordinates and the devising of the structure of authority is the responsibility of top management. It is for top management to devise, and for intermediate management to operate, that system of communications with which the small unit can dispense but which must grow more complex, with increasing size, if instructions are to be understood and morale-destroying misunderstandings are to be avoided. The need of such a system should not be a permanent and inherent handicap of size.

The real difficulty of the big organization, however, springs from the calls that it makes on managerial ability ; these outrun the supply of adequately trained managers. The small unit can get on with managers who are competent technicians and reasonably forceful, fair-minded and intelligent characters; the large unit needs specialists, and these, in the numbers required, simply do not exist. The lost-time rates of the large-scale units, and the inadequate morale of which these are largely the symptom and index, reflect this deficiency. To overcome it is an essential step both towards saving the material waste caused by lost time and towards creating a humanly satisfying climate in large-scale industry.

T. H. HAWKINS

\section{CONTROL OF PUBLIC EXPENDITURE ON SCIENTIFIC PROJECTS}

$\mathrm{T}$

$\mathrm{HE}$ third report from the Committee of Public Accounts for the Session 1956-57 has recently been issued*. Reference is made in it to the Treasury Minute of January 31, 1957, rejecting the Com mittee's recommendation that the Comptroller and Auditor-General should have access to such papers and records of the University Grants Committee as related to non-recurrent grants to the universities; and the Committee expresses appreciation of the fact that, by ensuring that in future the accounting officer is better informed as to the projects on which voted money is being spent and by making much additional information available to the Comptroller and Auditor-General, the Treasury has gone some way towards meeting the Committee's wishes. The Committee recommends that the new arrangements proposed by the Treasury should be given a trial over a period of three years, when the matter might be further reviewed.

Among other matters discussed in this report is the grant by the Department of Scientific and Industrial Research to the University of Manchester towards the construction of the radio-telescope at

* Third Report from the Committee of Public Accounts, Session 1956-57. Pp. 36. (London: H.M. Stationery Office, 1957.) 1s. net.
Jodrell Bank. Originally estimated in March 1952 to cost $£ 335,450$, including four years running expenses, the cost had risen in May 1953 to $£ 439,616$, towards which the Nuffield Foundation had agreed to contribute $£ 200,000$ and the Department $£ 230,000$, subject to some conditions relating to financial control, including the requirement that the Department should be consulted if any substantial variation from the expenditure detailed in the approved estimate became necessary. The University entrusted the design work and supervision of construction of the telescope to a firm of consultant engineers under an agreement which provided inter alia that prior approval of the University should be obtained for any serious modification of the design or in the cost of the work and for any large variations of contracts, which were to be let only with the written authority of the University. Further rises in costs before the work was completed were expected, and in November 1954 the University notified the Department that the May 1953 estimate might be exceeded by $£ 50,000$. In October 1955, however, the University informed the Department orally that the increase was likely to be $£ 240,000$ and that it had become clear that the design had been changed substantially without the University's approval. A committee of inquiry was set up jointly by the Department, the Nuffield Foundation and the University, and this committee, which reported on March 15, 1956, recorded what the Department described to the Treasury as a very unsatisfactory position as between the University and the consultants. Nevertheless, the Department considered it imperative that the telescope should be completed and recommended a further grant of one-half the cost above the $£ 430,000$ already provided, subject to a limit of $£ 130,000$.

The Department informed the Committee of Public Accounts that normally it stated the terms under which the grant would be given to a university, and then trusted the university to expend the grant in a reasonably competent manner: the Department would not intervene in negotiations between a university and its contractors. It was also stated in evidence that the engineering consultant changed the design without the concurrence of the University of Manchester, introducing new structural features which materially increased the complexity and cost; but Prof. A. C. B. Lovell, who was primarily responsible for the outline design and lived on the spot, was apparently not even consulted. The Treasury also agreed that expenditure on the telescope had not been properly controlled and administered by the University, which had not adopted the normal procedure of setting up a building sub-committee to process construction throughout: the Treasury has made the establishment of such a committee a condition of a further grant.

Criticizing the Department for not inquiring more closely into the University's arrangements with the consultant engineers and into the system of control over the design and construction work, the Committee of Public Accounts recommends that in future, when Government departments entrust substantial grants to universities for specific projects, they should seek the advice of the University Grants Committee on such matters as definition of contracts, establishment of university sub-committees responsible for executing the projects and any other measures necessary to control and supervize capital expenditure. 